\title{
Cross-Linguistic Collocations Used by Bilingual Native Speakers-A Case Study of Komi-Permyak-Russian Bilinguals ${ }^{1}$
}

\author{
By Yuliya Leshchenko* \\ Tamara Dotsenko \\ Tatyana Ostapenko
}

\begin{abstract}
This paper deals with a particular case of native bilingualism (a situation of spontaneous acquisition of two languages in early childhood in natural linguistic environment) characteristic for speakers of the Komi-Permyak and Russian languages. The Komi-Permyak language is based on the Cyrillic script and, due to long-term contacts with the Russian language, combines the native Finno-Ugrian vocabulary and morphology with a large number of Russian borrowings. Close coexistence of the Komi-Permyak and Russian languages results in their extensive interaction and mutual influence in bilingual consciousness. The experimental research that involved free associative tests with Komi-Permyak and Russian stimuli and a sociolinguistic survey demonstrates that joining Komi-Permyak and Russian words within one phrase is a highly productive strategy for Komi-Permyak - Russian adult bilingual speakers. As long as cross-linguistic word combinations are characterized by high usage frequency both in speech perception and production, we specify them as cross-linguistic collocations - habitual, repeatedly used semantically and syntactically holistic speech units. We suppose that extensive use of cross-linguistic word-combinations (collocations among them) proves the existence of a contiguous ("fused" from the point of view of language code) zone in bilingual consciousness with elements not marked as belonging to one particular language only. Obviously, due to a high degree of formal similarity of Komi-Permyak and Russian syntactic structures, as well as to a large number of Russian borrowings in the KomiPermyak language, such elements are intuitively interpreted as interchangeable/universally referring to both languages, or none of them in particular. All facts considered, we claim that the existence of the "fused" zone of syntactic and lexical representations in bilingual mental lexicon provides the basis for extensive unintentional code-switches in bilingual speech.
\end{abstract}

Keywords: Bilingual consciousness, Code-switches, Collocations, Cross-linguistic influence, Native bilingualism

\section{Introduction}

\section{Native Bilingualism in Russia}

Bilingualism in linguistics is usually referred to as ability of a certain social group/or a certain individual to use two languages for communication (Cummins 1978, Grosjean 1982, Cook 1992, Bialystok 2001). Different researchers offer different typologies of bilingualism based on taking into account various factors

\footnotetext{
*Associate Professor, Perm State National Research University, Russia.

${ }^{\dagger}$ Associate Professor, Perm State Humanitarian Pedagogical University, Russia.

* Senior Lecturer, Perm State Humanitarian Pedagogical University, Russia.

${ }^{1}$ The research is supported by the Russian Foundation for Basic Research, grant №17-29-09074

"Combined trilingualism and its influence on linguistic and cognitive activity of an individual: an integrative model"
} 
connected with the acquisition and use of the two languages. Thus, several bilingualism types are discussed in various sources: early vs. late bilingualism, native vs. classroom bilingualism, simultaneous vs. sequential bilingualism, balanced vs. unbalanced bilingualism, and some others (see, e.g., Appel and Muysken 1987, Myers-Scotton 2008, Ellis 1997, etc.).

The authors of the present paper rely on the subdivision of bilingualism into the native and non-native ones; in more detail, we discuss the situation of native bilingualism. A social group/a person can be described as natively (naturally) bilingual when acquisition of two languages is characterized as spontaneous - it occurs casually in natural language environment and is not based upon resultoriented (either classroom or otherwise) teaching and learning (Hamers and Blanc 1989, Romaine 1995).

Native bilingualism is a common situation on the territory of the Russian Federation; most often this type of bilingualism is encountered within the regions where ethnic groups other than Russian reside. In this case, the co-existence of the two languages is observed. They include the ethnic language which serves as a means of everyday domestic/intra-familial communication and the Russian language - the official state language of the country - used in more authoritative situations. In such regions the acquisition of the two languages (the ethnic/national language and the Russian language) occurs, as a rule, naturally and in early childhood; in other words, early native bilingualism is thus formed. Generally, such situation is referred to as national - Russian bilingualism (in case the national language was the first one to be acquired and then, after a short period of time, was followed by the Russian language) or Russian - national bilingualism (with Russian as the first acquired language succeeded by the national language acquisition).

The interrelation of languages of a national - Russian bilingual is determined by a multitude of factors. These include a number of social functions performed by each language and their significance, the variety of communicative spheres maintained by the two languages, the cumulative size of scientific, literary, media and other texts in the two languages, the social status of each language, etc. (Leshchenko 2018). As long as different national - Russian regions can be characterized by different distribution of the factors mentioned above, each type of national - Russian bilingualism can have certain specific features and, therefore, should be studied separately.

\section{Komi-Permyak - Russian Native Bilingualism}

The present study considers the case of bilingual native speakers of the Komi-Permyak and Russian languages which co-exist on the territory of the Komi-Permyak District in Russia. The Komi-Permyak District was first formed into a separate administrative-territorial entity within the Russian territory in 1925 and, for a long time, had the status of the national autonomous territory. Nevertheless, it was later integrated into the Perm Region, and since 2005 it has been referred to as "a national territory with a special status" (The KomiPermyaks 2008). The territory is situated in the north-west of the Perm Region, 
to the west of the Ural Mountains, with the main location in the upper part of the Kama river basin. Its total area is over $32,000 \mathrm{~km}^{2}$ and, according to the data of the all-Russian census, the population of the Komi-Permyak District is estimated over 80,000 people (The Komi-Permyaks 2008).

The Komi-Permyaks, whose history dates back to the $15^{\text {th }}$ century, are representatives of the Finno-Ugrian national group. The language of the KomiPermyaks (the Komi-Permyak language) for a long time existed only as a spoken dialect; the emergence of its literary written form was officially recorded only in the beginning of the $20^{\text {th }}$ century. The main peculiar feature of the Komi-Permyak language is that it combines the native Finno-Ugrian vocabulary and morphology with the original Cyrillic script (the Russian alphabet) and, moreover, includes a large number of native Russian borrowings (Lytkin 1962). Therefore, while KomiPermyak essentially exists and functions as a self-sufficient independent language, it has a certain set of similarities with Russian.

According to the data of sociolinguistic surveys (Leschenko and Ostapenko 2014), in the majority of cases both the Komi-Permyak and Russian languages are usually acquired spontaneously in early childhood (most often their acquisition occurs simultaneously). Various case studies show that the two languages are widely used on the territory of the Komi-Permyak District, though they are characterized by different status and functional variety. To exemplify, KomiPermyak serves as the basic means of intra-familial and everyday communication, while Russian functions as the main language used in more official spheres.

Therefore, the Komi-Permyaks refer to the group of native early bilinguals with approximately balanced proficiency and usage frequency of the two languages, but with certain differences in their functionality.

As a matter of fact, both Komi-Permyak and Russian are frequently used in educational environment. Both languages are the means of teaching in primary school; in secondary/high school the majority of academic subjects are taught in Russian, while Komi-Permyak is studied as a compulsory special subject. Those Komi-Permyaks who wish to get higher education and specialize as teachers of both the Komi-Permyak and Russian languages and literature are trained at the Komi-Permyak department of the Philological Faculty of Perm State Humanitarian Pedagogical University - the only higher education institution in Russia that provides professional study of the Komi-Permyak language.

\section{Bilingual Code-switches and Cross-linguistic Collocations}

Close co-existence of the two languages and their alternate usage results in widespread processes of cross-linguistic interaction and interference. The mutual interaction of the two languages can occur on different levels of linguistic system and can be revealed in various linguistic processes. It is generally assumed, that one of the most frequent manifestations of the cross-linguistic interaction process is that of cross-linguistic shifts or code switches. Despite the fact that the problem of code switches is widely discussed in linguistics (Poplack 1980, Myers-Scotton 1993, Muysken 2000), sociolinguistics (Gumperz 1982), psycholinguistics 
(Grosjean 1995, Lipski 2005), there is still no commonly used and generally agreed upon definition of the term (Clyne 2003).

Different authors resort to different definitions of the code-switching phenomenon. Thus, according to Haugen (1953), code-switching is defined as a case when a bilingual uses a fully unassimilated word in his/her speech. MyersScotton (1993) defines code-switching as a choice of a linguistic form that belongs to the embedded language and its usage while communicating in the matrix language.

Most linguists rely on general understanding of code switching as any concurrent use by the speaker of units of two or more languages within one and the same communicative act (Gardner-Chloros 1991, Figueroa 1995). Code switching emerges as the result of interaction of several linguistic systems and is considered to be dynamic in character. The authors of linguistic/sociolinguistic research mention that switching the code is determined by various linguistic and extra-linguistic factors, such as spheres of communication, the language of the addressee, personal motives and attitudes, etc. (Marian 2009, Myers-Scotton 1993, de Bot et. al. 2009, Dijkstra 2003, Winford 2003). Certain peculiar features of code switches (their frequency, direction and variety) are to a great extent conditioned by the type of bilingualism in question, so in each concrete case (for any concrete bilingualism type) variable data of code switches can differ.

In the present paper the authors consider one particular type of code switches, namely, the case when bilinguals while speaking combine words of two different languages within one phrase (a two-word/three-word combination) that can be regarded as a collocation.

A collocation is usually understood as a stable, habitual combination of two or more words that has the features of semantically and syntactically holistic unit and realizes regular combinatorial features of words based on the so-called "high expectancy" of their co-occurrence (Vlavatskaya 2015: 57). Linguists suppose that collocations occupy an intermediate position between idioms and free word combinations (Dobrovol'skiy 2012) One element of a collocation is not free and partially acquires idiomatic meaning, while the second element preserves its free combinatorial features. As a result, on the one hand collocations prove to be not very strictly bound speech units, but on the other hand, they turn out to be steadier than free word combinations. Therefore, collocations occur in speech "more often than it could be expected judging by chance distribution of their elements" (Woolard 2000: 28). Some common examples of widespread collocations include the following: to engage in conversation, to lay emphasis, to broaden horizons (Vlavatskaya 2015: 58); to give a hand, to give advice, to do a favor (Byalek 2004: 223), etc.

It is assumed that native speakers use collocations unconsciously and intuitively, reproducing them in their speech as a holistic unit (Mel'čuk 1998). Apparently, collocations are based on certain automated mechanisms which underlie the formation of lexical skills and fix in individual linguistic consciousness usual patterns of combining two words of the native language. 


\section{Experimental Research: Material and Methodology}

Our research is based on the following hypothesis: it is highly probable that simultaneous formation of lexical skills in relation to two languages can result in the fact that bilingual speakers develop a habit of using not only conventional intra-linguistic collocations, but also cross-linguistic ones. To verify this hypothesis, we carried out a cross-disciplinary (at the junction of psycholinguistics and sociolinguistics) experimental research.

\section{The Research Participants}

The participants of the research were 65 students of the Komi-Permyak Russian department of the philological faculty at the Perm state humanitarian pedagogical university aged from 18 to 25 years old. All the participants are getting higher education as school teachers of the Komi-Permyak and Russian language and literature. In accordance with the curriculum of the Komi-Permyak Russian department, all academic subjects connected with the Komi-Permyak language, literature, folklore etc. are predominantly taught in the Komi-Permyak language (the Native Language, History of the Native Language, History of the Native Literature, Native Dialectology, etc.), while all the other subjects - those that refer directly to the Russian language and literature (the Russian Language, Russian Literature, History of the Russian Literature, Russian Folklore etc.), as well as to all general subjects (World History, Philosophy, Psychology, Pedagogy, Information Technologies etc.) - are taught in Russian. Thus, on the one hand, educational environment at the university is characterized by significant preponderance of the Russian language usage frequency as compared to KomiPermyak usage frequency. On the other hand, in the situation of professional linguistic competence formation both languages are resorted to with approximately equal frequency.

The research included two stages: Stage 1 (a psycholinguistic experiment) and Stage 2 (a sociolinguistic experiment).

\section{Stage 1: The Research Procedure}

At the first stage of our research the participants took part in the free associative test (carried out in written form) with Komi-Permyak and Russian stimuli. During the test the Komi-Permyak - Russian bilingual speakers were given a list of 54 high frequency words presented at random: friend, think, picture, usually, man, go, big, name, girl, time, listen, summer, know, work, famous, weather, come, easy, morning, world, speak, dictionary, boy, quickly, example, over, book, do, day, give, house, study, street, begin, woman, understand, read, new, sentence, like, evening, teacher, small, take, page, good, family, student, paper, language, word, have. While fulfilling the experimental task the participants had to produce to each stimulus a reaction word that first occurred to them; the language of the reaction word was not specified. 
The test was carried out twice: first the trial with the stimuli in the KomiPermyak language was presented (ерт, думайтны, морт, мунны, ььджыт, ним, ныввкаок, пора, кывзыны, гожум, удж, тӧдны, уналӧ тӧдса, погоддя, вовлыны, кокнита, асыв, югыт, баитны, кывчукӧр, зоночка, чожа, мыччалӧм, чайтны, сайын, небӧг, керны, сетавны, керку, велӧтчины, ӧтӧр, пондӧтны, инька, вежӧртны, дылдьӧтны, виль, серникузя, любитны, рыт, велотісь, учӧтик, босьтны, листбок, бур, кьлв,лун, имейтны) and, secondly, the trial with the identical stimuli in the Russian language (друг, думать, картина, обычно, человек, идти, большой, имя, девочка, время, слушать, лето, знать, работа, знаменитьій, погода, приходить, легко, утро, мир, говорить, словарь, мальчик, быстро, пример, полагать, через, книга, делать, день, давать, дом, учиться, улица, начинать, женщина, понимать, читать, новый, предложение, любить, вечер, учитель, маленький, брать, странища, хороший, семья, студент, бумага, брать, язык, слово, иметь). In both tests Komi-Permyak and Russian words followed each other in precisely the same order; the task in both tests was also identical and was given in the Komi-Permyak or Russian language respectively. The time lapse between the tests with KomiPermyak and Russian stimuli made up about four weeks: we assumed, that this period was long enough for our participants to produce the reactions anew in the second test.

\section{Stage 1: The Research Results}

As a result of two experimental trials (one with the Komi-Permyak stimuli and one with the Russian stimuli) over 3,500 reactions in different languages were received and further analyzed. We used an associative-verbal pair - a combination of the stimulus word with its verbal reaction - as the basic unit of the analysis (e.g., house $\rightarrow$ new, read $\rightarrow$ book, go $\rightarrow$ fast).

All associative-verbal pairs were divided into two main groups: intra-lingual and inter-lingual ones. Intra-lingual associative-verbal pairs are represented by a word-stimulus and a word-reaction belonging to the same language - Russian (е.g., девочка $\rightarrow$ маленькая/ "girl $\rightarrow$ little") or Komi-Permyak - (e.g., имейтнь $\rightarrow \ddot{e p m} /$ "have $\rightarrow$ a friend") ${ }^{2}$. As for inter-lingual associative-verbal pairs the stimulus and the reaction words belong to different languages - a Komi-Permyak stimulus is followed by a Russian reaction (e.g., имейтнь $\rightarrow$ семью/ "have a family") or a Russian stimulus is followed by a Komi-Permyak reaction (e.g., погода $\rightarrow$ бур/ "weather $\rightarrow$ nice"). The proportion of intra-lingual and interlingual pairs is presented in Diagram 1.

\footnotetext{
${ }^{2}$ Here and elsewhere original stimuli and their reactions are given in italics; each associativeverbal pair in Komi-Permyak and Russian are followed by the English translation indicated by a slash and quotation marks.
} 
Diagram 1. The Percentage of Intra-Lingual and Inter-Lingual AssociativeVerbal Pairs Received in Two Experimental Trials with the Komi-PermyakRussian Bilingual Speakers

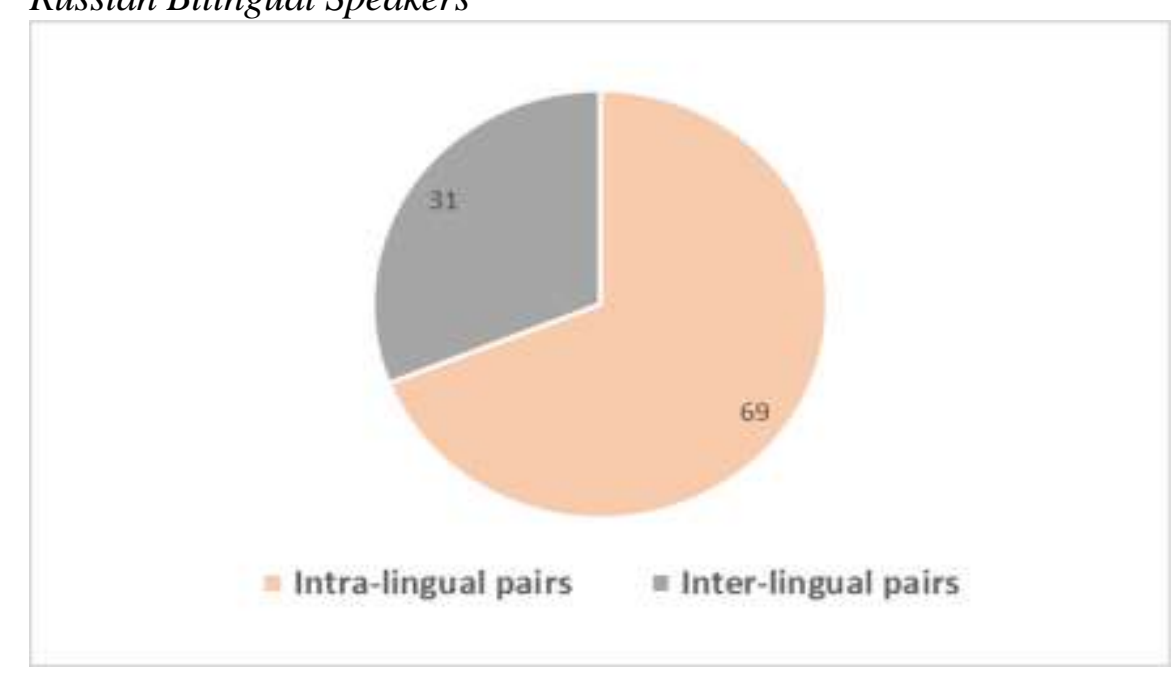

As the data presented in Diagram 1 show that, though the quantity of intralingual "stimulus $\rightarrow$ reaction" pairs apparently prevails in the whole total of all the associative-verbal pairs received (their number amounts to 69\%), the percentage of inter-lingual pairs is also significant (it makes up one-third of all the pairs). At the same time, it should be noted that in the majority of the cases the inter-lingual pairs were received for the Komi-Permyak stimuli, so they were produced according to the "Komi-Permyak word $\rightarrow$ Russian word" pattern, whereas only few examples of the "Russian word $\rightarrow$ Komi-Permyak word" pattern were revealed.

We assume that the occurrence of inter-lingual pairs in the associative tests demonstrates the activation of the mechanism of cross-linguistic interactions in mental lexicon of bilingual speakers. Therefore, a great predominance of interlingual reactions for the Komi-Permyak stimuli over the Russian ones presumably demonstrates that the Komi-Permyak language possesses highly penetrable boundaries in the consciousness of Komi-Permyak - Russian speakers: KomiPermyak words are freely included into the Russian associative contexts and, in this way, are interacting extensively with Russian words. On the contrary, the Russian language seems to be characterized by a much more isolated position and non-penetrable/low-penetrable boundaries; this makes the inclusion of Russian words into Komi-Permyak contexts hardly probable. In other words, the revealed tendency proves that Russian tends to preserve the position of the matrix language for Komi-Permyak - Russian speakers, while Komi-Permyak mostly functions as the embedded language.

Such results fully correlate with the data of our previous socio-linguistic surveys with Komi-Permyak - Russian bilingual students (Leshchenko, Ostapenko 2014) showing that, compared to the Komi-Permyak language, the Russian language is more frequently used, covers a wider set of communicative spheres and, generally, performs a larger number of various functions. Thus, the more functional language (Russian) dominates over the less functional one (Komi- 
Permyak). This domination is manifested in the unidirectional character of crosslinguistic interactions: they are realized in the direction from the Komi-Permyak language to the Russian language, but do not proceed in the reverse direction.

A detailed analysis of the inter-lingual associative verbal pairs showed that their majority are formed within the syntagmatic pattern and represent a combination of the Komi-Permyak stimulus with the Russian reaction. Such crosslinguistic combinations make up semantically and syntactically united holistic units based on linear extension of the stimuli: думайтны ("think") $\rightarrow$ о чём-то ("about smth"), кывзыны ("listen") $\rightarrow$ внимательно ("attentively"), гожум ("summеr") $\rightarrow$ солнечный ("suпnу"), вовльныь ("соте") $\rightarrow \kappa$ тебе ("tо уои"), мунны ("go") $\rightarrow$ далеко ("far away"), бур ("nice") $\rightarrow$ погода ("weather"), имейтны ("have") $\rightarrow$ друзей ("friends"), босьтнь ("give") $\rightarrow$ знания ("knowledge"), велотісь ("teacher") $\rightarrow$ умный ("clever").

As long as cross-linguistic syntagmatic pairs were encountered almost in every experimental answer sheet, we hypothesized that the strategy of integrating words of two different languages into a single syntactic pattern is highly productive for Komi-Permyak - Russian bilinguals. Moreover, some crosslinguistic combinations can be reproduced by the speakers (and perceived by the listeners) as conventional, natural and linguistically correct, i.e. can be considered as cross-linguistic collocations.

\section{Stage 2: The Research Procedure}

In order to prove this hypothesis, at the second stage of the research we carried out a written survey with the same Komi-Permyak - Russian bilingual students. For this survey out of all the cross-linguistic syntagmatic associativeverbal pairs 51 units were chosen with the help of the manual sampling method.

As a result, we received a list of the following cross-linguistic word combinations: керны на совесть ("dо properly"), вовлынын на пары ("соте tо the lessons"), кывзыны внимательно ("listen attentively"), вовлыны вовремя ("соте on time"), думайтны о будущем ("think about the future"), кыв родной ("native language"), тӧдны домашнее задание ("know the hometask"), сетавнь конфет ("give sweets"), баитны ни о чём ("talk about nothing"), думайтны о чём-то ("think about something"), велӧтчинь в вузе ("study at university"), мунны гулять ("go for a walk"), зонка симпатичный ("handsome boy"), кывзыны лекцию ("listen to the lecture"), кывззыны окружающих ("listen to other people"), тӧдны о себе ("think about oneself"), керны работу ("do work"), учӧтик ребёнок ("a small child"), чожа делать ("do quickly"), муннь домой ("go hоте"), вежӧртны жизнь ("love life"), вовльныь домой ("соте hоте"), льддьӧтны книгу ("read a book"), учӧтик собака ("a small dog"), баитнь много ("speak тисh"), вовльныь в кино ("go to the cinema"), кывзыныны товарища ("listen to a friend"), ьыджыт дом ("a big house"), вежёртнь окружающих ("understand people"), вежёртны тему ("understand the topic"), имейтны всё ("have everything"), морт маленький ("a short man"), морт высокий ("a tall тап"), чожа идти ("gо quickly"), лун сегодняшний ("present day"), погоддя плохая ("nasty weather"), погоддя хорошая ("nice weather"), 
инька хорошая ("a good wотап"), нывка красивая ("a pretty girl"), нывка маленькая ("a little girl"), удж тяжёлая ("hard work"), кокнита прибежать ("run quickly"), сёрникузя пройтись ("an invitation for a walk"), гожум жаркое ("hot suтmеr"), баитны смеясь ("speak laughing"), керку высокий ("а big house"), лун хороший ("а good day"), кыв длинный ("a long tonguе"), сёрникузя о жизни ("a sentence about life"), pыт тёмный ("a dark evening"), велӧтісь добрый ("a kind teacher").

In the course of the survey the respondents were presented a table with the list of the 51 cross-linguistic combinations mentioned above; each combination had to be specified in the corresponding column in the table by answering the three questions: 1) Do you hear these word combinations from other people? 2) Do you use such word combinations in your own speech? 3) Can you comment on these word combinations? Answering the first and the second questions the respondents had to put a tick or a cross into the respective column; as for the third question, it implied some verbal manifestation/explanation.

By asking these questions we aimed to find out whether the selected crosslinguistic word combinations are used in the speech of the Komi-Permyak Russian bilinguals and, if so, to reveal the degree of their functional activity in speech production (output) and speech perception (input).

\section{Stage 2: The Research Results}

The survey results demonstrated that among the 51 cross-linguistic word combinations 48 ones (94\%) were marked by the informants as being both used and heard. It should be mentioned that, though two positive answers ("I hear" and "I use") for every combination were present at least in some answer sheets, the percentage of these answers is higher for the input and less for the output, which means that they are more often heard from the environment than produced by the speaker himself/ herself.

For the purposes of further analysis we subdivided the whole list of crosslinguistic word combinations into 4 frequency intervals: 1) combinations with individual frequency/sporadic combinations (those marked as used and heard only by one respondent); 2) low-frequency combinations (marked as used and heard by $4-19 \%$ of the respondents); 3) combinations with medium frequency (marked as used and heard by $20-49 \%$ of the respondents); 4) high-frequency combinations (marked as used and heard by more than $50 \%$ of the respondents).

Below the list of cross-linguistic word combinations grouped according to their frequency index is presented.

Individual combinations: нывка красивая ("a pretty girl"); кыв длинный ("a long tonguе"); инька хорошая ("a good woman").

Low-frequency combinations: удж тяжелая ("hard work"); баитнь много ("speak тисh"); нылкка маленькая ("a little girl"); кокнита прибежать ("run quickly"); баитны смеясь ("speak laughingly"); сёрникузя пройтись ("ап invitation for a walk"); керку выссокий ("a tall building"); морт высокий ("a tall тап"); погоддя хорошая ("nice weather"); морт маленький ("a short man"); чожа идти ("gо quickly"); лун хороший ("a good day"); ьыљжыт дом ("a big 
house"); лун сегодняшний ("today"); чожа делать ("do quickly"); имейтнь всё ("have everything"); погоддя плохая ("bad weather"); кывзыны товарища ("listen to a friend"); кывзыны окружающих ("listen to others"); учӧтик собака ("a small dog"); вовльны в кино ("go to the cineта"); вежӧртны тему ("understand the topic"); вовльны домой ("gо hоте"); мунны домой ("соте hoте"); льлдьӧтнь книгу ("read a book"); вежӧртны окружаюших ("understand others"); учӧтик ребёнок ("a little child"); вежӧртны жизнь ("understand life"); думайтны о чём-то ("think about something"); велӧтісь добрый ("a kind teacher"); керны работу ("do work").

Combinations with medium frequency: кывзыны лекцию ("listen to the lecture"); зонка симпатичный ("a handsome boy"); сетавны конфет ("give sweets"); тӧдны о себе ("speak about oneself"); баитны ни о чем ("talk about nothing"); мунны гулять ("go for a walk"); велӧтчины в вузе ("study at university"); кьвв родной ("native language"); тӧдны домашнее задание ("dо hoтеwork"); думайтны о будущем ("think about the future").

High-frequency combinations: вовлыны вовремя ("соте on time"); кывззыны внимательно ("listen attentively"); вовльнын на пары ("соте to the lessons"); керны на совесть ("do properly").

As for the comments to the given cross-linguistic word combinations (Question 3 in the survey), they were produced only by a part of the respondents (23\% of students someway or other specified this or that aspect of their usage). The number of the comments presented in one answer sheet varies from 1 to 24 ; the total number of the received comments is 90 .

Generally, three types of the comments were singled out:

1. in $90 \%$ of cases the participants produced the Komi-Permyak equivalent of the cross-linguistic word combination given in the survey: роднӧй кыв ("native language"), уна баитны ("speak a lot"), вовльны киноё ("gо to the cinema");

2. $8 \%$ of cases represent the estimation by the participants of the frequency with which the given cross-linguistic word combinations are used: rarely used, frequently used;

3 . in $2 \%$ of cases the participants specified the sphere where certain crosslinguistic word combinations are used: while talking to friends, at the lesson.

\section{Discussion}

The analysis of the experimental material (results of free associative tests with Komi-Permyak and Russian stimuli and results of the survey about the general usage frequency of cross-linguistic Komi-Permyak - Russian word combinations) show that the tendency of joining words of two different languages according to the pattern "a Komi-Permyak word + a Russian word" seems to be a highly productive strategy for Komi-Permyak Russian bilingual speakers. Subsequently, it can be assumed that cross-linguistic combinations that received a high level of 
coherence in both "I hear" and "I use" responses in the survey can be treated as regular and conventional for Komi-Permyak - Russian native speakers. It is obvious, that combinations of this kind are often used and perceived in their speech and, therefore, are characterized by a high degree of reproducibility. Consequently, this allows us to regard the Komi-Permyak - Russian word combinations as cross-linguistic collocations.

As it has been mentioned in the previous parts of the article, cross-linguistic collocations are based on the code-switching process - that of alternation of different languages within one communicative unit caused not by the intentions of the speaker, but by some specific conditions of speech production (Wei 2002, Riehl 2005). It is well-known that switching linguistic code is stimulated by the triggering mechanism which is generally understood as the influence of some linguistic unit on shifting from one language to another (Clyne 1980, Broersma and de Bot 2006). Therefore, for the purposes of our research we tried to reveal what linguistic (or extra-linguistic) properties could serve as triggers for shifting from a Komi-Permyak word to a Russian word.

The analysis of our research material allowed us to reveal two types of triggers: 1) a linguistic trigger and 2) an extra-linguistic trigger. It is obvious, that both types reach the threshold level of activation and evoke code-switches in case a bilingual is highly proficient in both languages and, particularly, has a good command of their syntactic structures and lexical-semantic systems.

Linguistic triggers are represented by the borrowed Russian words that were adopted by the Komi-Permyak language at some stage of its development for a variety of reasons: filling up a vocabulary gap in the Komi-Permyak language by a Russian word, emerging of a Russian synonym for a Komi-Permyak word that further developed its own meaning and became a separate lexical-semantic unit, the substitution of a Komi-Permyak word by a Russian synonym for convenience reasons (in case the Russian equivalent has a simpler morphological structure and a wider set of combinatorial patterns), etc. In our experimental material word combinations with Russian borrowings are represented by the following examples: думайтны ("think") о чём-то ("about something"), думайтны ("think") о будущем ("about the future"), имейтны ("have") всё ("everything"), погоддя ("weather") хорошая ("nice"), погоддя ("weather"), плохая ("bad").

All the examples given above show originally Russian words that were borrowed by the Komi-Permyak language and underwent partial morphological assimilation: they preserve the Russian root morpheme and add originally KomiPermyak affixes.

Thus, Russian borrowings думайmны ("think"), имейтны ("have") possess the Russian verb root думать, иметь, but add the Komi-Permyak infinitive inflexion $H b l /-b l H b l$, which refers the word to the verbal class in the KomiPermyak language: льддьӧтны ("read"), велӧтчины ("study"), кывзыныь ("listen") (Lytkin 1962). The Russian borrowing погоддя ("weather") preserves the Russian noun root nozod-; meanwhile, its grammatical adaptation to the noun class in the Komi-Permyak language is followed by both morphological and phonological changes (adding the Komi-Permyak noun suffix - $\boldsymbol{\partial} \boldsymbol{r}$ ). 
In consequence of these processes, the Komi-Permyak language has acquired a large number of words characterized by a high degree of formal (phonetic and orthographic) and semantic similarity with the equivalent Russian words, for example: иметь (Russian) - имейтны (Komi-Permyak), думать (Russian) думайтны (Komi-Permyak), погода (Russian) - погоддя (Komi-Permyak), etc. Apparently, this similarity triggers numerous code-switches from the KomiPermyak to the Russian language which leads to the emergence of Komi-Permyak - Russian word combinations. In their turn, due to their highly productive pattern and extensive usage in the speech of Komi-Permyak - Russian native speakers, such combinations gradually develop the status of cross-linguistic collocations.

As for extra-linguistic triggers, we suppose that they are represented by the referential attributes of the Komi-Permyak words - namely, by their capability to be included into the academic communicative context: вовльнын на пары ("attend lessons"), велӧтчыны в вузе ("study at university"), тӧдны домашнее задание ("do homework"), кывзыны лекцию ("listen to the lecture"). While describing the linguistic background of the participants of our experiment we drew attention to the fact that they are students of the Komi-Permyak-Russian department at the Perm state humanitarian-pedagogical university. The city of Perm is situated rather close to the Komi-Permyak District, albeit not part of it, so the linguistic background in Perm is Russian monolingual. Therefore, the academic (higher educational) context that our participants are surrounded by is almost fully Russian with the only difference that they have a number of academic subjects conducted in the Komi-Permyak language. Consequently, it was quite predictable that the Komi-Permyak words that refer the participants to the academic context will serve as triggers, directing their cognitive efforts towards the Russian language.

The two trigger types stated above can apparently be distinguished as underlying high-frequency and medium-frequency Komi-Permyak - Russian word combinations that can be referred to the group of cross-linguistic collocations. Nevertheless, the analysis of low-frequency and individual combinations of KomiPermyak and Russian words obviously shows that they are conditioned by some other types of triggers - those that can be referred neither to Russian borrowings, nor to belonging to the academic context. Such word combinations are hard to be referred to collocations per se, as their usage frequency (according to our survey results) does not reach the statistically significant level. Nevertheless, generally they prove to be quite numerous and appear to be used and perceived by a certain number of the Komi-Permyak - Russian speakers; this fact makes it possible to regard the like combinations as potential or "dormant" collocations or crosslinguistic combinations that, under certain conditions, can change their linguistic status and become collocations as such.

Examples show that there is quite a high number of Komi-Permyak - Russian word combinations that are on the verge of becoming regular collocations in the speech of Komi-Permyak - Russian bilinguals. They are represented by various examples, so that finding a definite type of trigger in this case seems to be quite ambiguous. Still, we have revealed the general common feature that can be found in all combinations of this type - namely, the structural and semantic similarity of the syntactic pattern of the combination in the Komi-Permyak and Russian 
languages. This similarity concerns both syntactic relations between the elements of word combinations - the existence of regular syntactic patterns such as "noun + attribute $(\mathrm{N}+$ modifier)/attribute + noun" (modifier $+\mathrm{N})$, "action + object" (VP/V $+\mathrm{NP})$, "action + its characteristics" (V + AdvP), and semantic ones (the possibility of filling in the slots of the common syntactic pattern by words with the same meaning).

For example, the cross-linguistic combination нывка маленькая ("a little girl") is based on the "noun + attribute" syntactic pattern universal for the KomiPermyak and Russian languages, so that identical intra-lingual combinations ньъкка - учӧтик (Komi-Permyak) and девочка маленькая (Russian) are quite common and regular in both languages. The same concerns such syntactic patterns as "action + object" (the cross-linguistic combination льљдьвӧнны книгу/"read a $b^{\prime} o o k^{\prime \prime}$ corresponds to the intra-lingual Komi-Permyak word combination льљдьвӧннь небӧг and Russian word combination читать книгу), or the syntactic pattern "action + its characteristics" (the cross-linguistic combination чожа идти/ "gо quickly" corresponds to intra-lingual чожа вовльны in KomiPermyak and идти быстро in Russian).

We assume that structural and semantic similarity of a word combination can be considered as a trigger for switching from the Komi-Permyak to the Russian language within a word combination. Such combinations seem to be entirely reproducible in case their divisibility into elements (words) allows a bilingual to choose freely among the pair of cross-linguistic synonyms. Apparently, due to the fact that vernacular speech norms are not strictly bound, the choice of a crosslinguistic synonym within a word combination can hardly influence the syntactic relations and, at the same time, does not change its meaning. Therefore, such combinations are becoming frequently used in bilinguals' speech.

The authors who deal with code-switching research draw attention to the fact that any phenomenon/item at some point connected with bilingual speech production may function as a trigger: "a sound of another language, a recollection of some event connected with the given communicative situation, frequency of occurrence of a sound/word/graphic sign/articulatory movement/a construction from another language can be enough for evoking a switch into another linguistic code" (de Bot et al. 2009: 88). Taking into account the fact that the share of crosslinguistic word combinations in our research material is large enough in size, we can assume that besides lexical similarity of borrowed words in the two languages and their referring to the academic communicative context, there exist a variety of other triggers that evoke code-switches in she speech of Komi-Permyak - Russian bilinguals. Closer study of such trigger types requires further research in this direction.

\section{Conclusion}

The experimental research with Komi-Permyak - Russian native bilingual speakers (free associative tests with Komi-Permyak and Russian stimuli and the survey on the general usage frequency of cross-linguistic Komi-Permyak - 
Russian word combinations) demonstrates that joining words of two different languages within the unified pattern "a Komi-Permyak word + a Russian word" seems to be a highly productive strategy for Komi-Permyak Russian bilingual speakers.

Some of these cross-linguistic word combinations are characterized by high usage frequency both in speech perception and production which allows to refer them to the group of cross-linguistic collocations - habitual, repeatedly used semantically and syntactically holistic lexical units based on regular combinatorial features of their elements.

The co-occurrence of words of two different languages within one wordcombination is determined by the code-switching mechanism which can be triggered by a borrowed word, a communicative context, or some other factors that need further detailed studies.

It can be assumed that extensive use of cross-linguistic word-combinations (collocations among them) that is typical for the speech of Komi-Permyak Russian native bilingual speakers proves the fact that their linguistic consciousness incudes a contiguous ("fused" from the point of view of linguistic code) zone with elements not marked as belonging to one particular language only. Obviously, due to the high degree of formal similarity of Komi-Permyak and Russian syntactic structures, as well as to a large number of Russian borrowings in the KomiPermyak language, such elements are intuitively interpreted as interchangeable/ universally referring to both languages or none of them in particular. This allows a bilingual individual to conjoin them freely within one semantic and syntactic pattern and, consequently, to perceive them as normal combinations that do not violate the linguistic homogeneity of an utterance.

All facts considered, it seems highly probable that the existence of the "fused" zone of syntactic and lexical representations in bilingual mental lexicon provides the basis for extensive unintentional code-switches in bilingual speech.

\section{References}

Appel R, Muysken K (1987) Language Contact and Bilingualism. Edward Arnold Ltd: London.

Bialystok E (2001) Bilingualism in Development: Language, Literacy, and Cognition. New York: Cambridge University Press.

Broersma M, de Bot K (2006) Triggered Codeswitching: A Corpus-based Evaluation of the Original Triggering Hypothesis and a New Alternative. Bilingualism: Language and Cognition 9(1): 1-13.

Byalek E (2004) A Collocation as a Unit of Translation (In Russian). Cuadernos de Rusistica Espanola 1: 223-231.

Clyne M (2003) Dynamics of Language Contact. Cambridge: Cambridge University Press.

Clyne M (1980) Triggering and Language Processing. Canadian Journal of Psychology 34(4): 400-406.

Cook VJ (1992). Evidence for Multi-competence. Language Learning 42(4): 557-591.

Cummins J (1978) Bilingualism and the Development of Metalinguistic Awareness. Journal of Cross-Cultural Psychology 9(2): 131-149. 
de Bot K, Broersma M, Isurin L (2009) Sources of Triggering in Code Switching. In L Isurin, D Winford K, de Bot (Eds.), Multidisciplinary Approaches to Code-switching (studies in bilingualism) (pp. 85-102). Amsterdam, The Netherlands: John Benjamins Publishing Company.

Dijkstra T (2003) Lexical Processing in Bilinguals and Multilinguals. In J Cenoz, B Hufeisen, U Jessner (Eds.), The Multilingual Lexicon (pp. 11-26). The Netherlands: Kluwer.

Dobrovol'skiy D (2012) Are Free-word Combinations really Free? (Lexical co-occurrence of the Russian degree modifier crezvycaino) (in Russian). Yearbook of Phraseology 3: 57-86.

Ellis R (1997) Second Language Acquisition. Oxford: Oxford University Press.

Figueroa L (1995) Knowing the Code. Hispanic 8: 14.

Gardner-Chloros P (1991) Language Selection and Switching in Strasbourg. Oxford: Oxford University Press.

Grosjean F (1995) A Psycholinguistic Approach to Code-switching: The Recognition of Guest Words by Bilinguals. In L Milroy, P Muysken (Eds.), One Speaker, Two Languages: Cross-disciplinary Perspectives on Code-switching (pp. 259-275). Cambridge: Cambridge University Press.

Grosjean F (1982) Life with Two Languages. An Introduction to Bilingualism. Cambridge, MA: Harvard University Press.

Gumperz J (1982) Discourse Strategies. Cambridge: Cambridge University Press.

Hamers J, Blanc M (1989) Bilinguality and Bilingualism. New York: Cambridge University Press.

Haugen E (1953) The Norwegian Language in America: A Study in Bilingual Behavior. Philadelphia: University of Pennsylvania Press.

Leshchenko Y (2018) Language Oppositions in the Situation of Combined Trilingualism (in Russian). Global Scientific Potential 6 (87): 18-21.

Leshchenko Y, Ostapenko T (2014) Non-equivalent Distribution of the Languages: A Psycholinguistic Study of Bilingual Code-switches. In SGEM Conference Proceedings. Psychology \& Psychiatry, Sociology \& Healthcare, Education, Albena, Bulgaria, August 29-31, 2014, pp. 601-608.

Lipski J (2005) A History of Afro-Hispanic Language: Five Centuries and Five Continents. Language in Society 36(3): 452-455.

Lytkin VI (1962) The Komi-Permyak Language: Introduction, Phonetics, Vocabulary and Morphology (in Russian). Syktyvkar: The Komi-Permyak Publisher.

Marian V (2009) Language Interaction as a Window into Bilingual Cognitive Architecture. In L Isurin, D Winford K, de Bot (Eds.), Multidisciplinary Approaches to Code-switching (studies in bilingualism) (pp. 161-185). Amsterdam, The Netherlands: John Benjamins Publishing Company.

Mel'čuk I (1998) Collocations and Lexical Functions. In A.P. Cowie (Ed.) Phraseology. Theory, Analysis, and Applications (pp. 23-53). Oxford University Press.

Muysken P (2000) Bilingual Speech: A Typology of Code-mixing. Cambridge: Cambridge University Press.

Myers-Scotton C (1993) Dueling Languages: Grammatical Structure in Code-switching. Oxford: Clarendon Press.

Myers-Scotton C (2008) Multiple Voices: An Introduction to Bilingualism. Australia: Blackwell Publishing.

Poplack S (1980) Sometimes I'll Start a Sentence in Spanish y teRMINo eN eSPaNol: Toward a Typology of Code-switching. Linguistics 18: 581-618.

Romaine S (1995) Bilingualism, Second Edition. Oxford: Blackwell.

Riehl CM (2005) Code-switching in Bilinguals: Impacts of Mental Processes and 
Language Awareness. In J Cohen, KT McAlister, K Rolstad, J MacSwan (Eds.), Proceedings of the $4^{\text {th }}$ International Symposium on Bilingualism (pp. 1945-1959). Somerville, MA: Cascadilla Press.

The Komi-Permyaks (2008) The Atlas of Cultures and Religions (in Russian). In V Tyshkov, A Zhuravskiy, O Kazmina (Eds.), Peoples of Russia. Moscow.

Vlavatskaya MV (2015) Combinatorial Lexicology: Functional - Semantic Classification of Collocations (in Russian). Philological Sciences. Questions of Theory and Practice 11(53): 56-60.

Winford D (2003) An Introduction to Contact Linguistics. Oxford: Blackwell.

Woolard G (2000) Collocation - Encouraging Learner Independence. In M Lewis (Eds.), Teaching Collocation (pp. 28-46). Boston, MA: Thomson Heinle.

Wei L (2002) The Bilingual Mental Lexicon and Speech Production Process. In Brain and Language (pp. 691-707). London: Elsevier Sciences. 